\title{
The Representation of Latin@s in Media: A Negation of Blackness
}

\author{
Yadira Nieves-Pizarro • Universidad Interamericana de Puerto Rico
}

\begin{abstract}
The denial of African ancestry in the articulation of Latin@ identity is evident in Latin@ media in the United States. Furthermore, there is limited representation of Afro-Latin@s in current programming even though they claim to appeal to all Latin@s in the US and in Latin America. This trend has its roots in Latin American discourse of mestizaje and reproduces itself in Latin American media content that is exported to the diaspora in the United States. This article reviews the sociological reasons for the invisibility of Afro descendants in Latin America and the Hispanic Caribbean. Finally, this manuscript will account for how this population has been represented in Latin American, Latin@, and US mainstream media.
\end{abstract}

Keywords: Latin@ identity, Latin American television, Latin@television, Latin@/Afro-Latin@ representation in media

$\mathrm{T}$ he concept Latin@1 has served as a political tool to advance recognition of Latin American immigrant groups in the United States. Nevertheless, United States notions of Latin@ rely on stereotypical shared characteristics such as cultural symbols and language. Moreover, Latin@s of African descent are invisible from the construction of the concept, as Black and Latin@ are separate and mutually exclusive categories that challenge the romantic notion of mestizaje. Likewise, blackness is habitually regarded as problematic to Latin@ identity creation (Hernández 2003; Newby \& Dowling 2007).

The negation of the African element in the Latin@ identity is perceived in Latin@ media in the United States. Television news, talk shows, and telenovelas have limited representation of Afro-Latin@s. Television networks such as Telemundo and Univision market an ideal Latin@ identity that transcends nationalities and appeals to Latin@s in the US and in Latin America (Sommers 1991). This image perpetuates the invisibility of Afro-Latin@s and the visibility of Latin@whiteness. In this article, I discuss the elements of latinidad and the challenges with identity that Afro-Latin@s face. Furthermore, I briefly consider the representations of Blacks in Brazilian, Colombian, Peruvian, Puerto Rican, Latin@, and United States television.

\section{Latin@Identity in the United States}

The development of panethnic identities in the United States is a product of US ethnic and racial classification. Immigrants from Latin America and the Hispanic Caribbean have been commonly branded as Latin@s. This category alludes to individuals from different countries and comprises immigrants and several generations of people born in the US, individuals of distinct socio-economic backgrounds and those who became part of the nation through territorial extension such as Puerto Ricans and part of the Mexican American population. For instance, Chicanos developed in isolation from the Mexican government and were subsequently cut off from the motherland as a result of the Mexican-American War in 1848.

In that same vein, Puerto Rico did not become a part of the US until 1898. The US took over the archipelago as a result of the Spanish-American War and has governed it as a colony since then. Through the Jones Act, Congress granted Puerto Ricans US citizenship in 1917. The ties between the United States and Puerto Rico, as well as economic problems, have promoted migratory waves towards the mainland after World War II and in the present decade. In general, Puerto Ricans settled in New York City, Chicago, and recently in 
Florida (Collazo, Ryan, and Bauman 2010; Motel and Patten 2012; Calderon 1992). Puerto Ricans have more freedom of mobility between the mainland and their homeland, which contributes to a strong Puerto Rican ethnic identity (Rodriguez-Cortez 1990; Cohn, Patten, and Lopez 2014; Calderon 1992).

Regardless of their place of origin, age group or financial status, in the United States, Latin@s embrace this space to build their individual and group identities, and for practical and emotional purposes (Itzigsohn 2004). Moreover, researchers conceive Latin@identity formation as a process. In general, common cultural characteristics; recognition as Latin@, rather than national-origin-based ethnicity; common political concerns; and increasing contact with Latin@ populations of different ancestries form the foundation of a Latin@ identity. Nevertheless, the embracing or rejection of this identity will depend on the individual's class, race, nation, religion, gender, sexuality, immigrant status, and generation. Each element assigns different and often contradictory meanings to what it is to be a Latin@ (Lavriega Monforti 2014; Itzigsohn 2004). Black identity is often made invisible in Caribbean and Latin American society, which influences Afro-Latin@s' self-identification.

Some scholars who study Latin@identity underscore the panethnic aspect of this concept. Panethnic groups are a conglomerate of individuals who represent separate nations but are bound together by supraethnic attributes, such as language and culture (Sommers 1991). Latino identity is also referred to as latinidad or latinismo (Lavriega Monforti 2014; Sommers 1991). Thus, the use of the Spanish language, ethnic-racial mixture, political socialization, and immigration are among the core cultural characteristics of Latin@ identity (Lavriega Monforti 2014). Nonetheless, Latin@ groups vary in historical experience, socioeconomic status, and identity (Calderon 1992). Upon considering Mexican Americans and Puerto Ricans, the two largest Latin@ groups in the United States, one has to conclude that their history and place of settlement in the United States makes them two distinct groups (Collazo, Ryan, and Bauman 2010; Motel and Patten 2012.

This article focuses on the racial aspect of latinidad. Throughout the history of the Hispanic Caribbean and Latin America, there has been a continuous intermingling of lineages producing hybrid populations of Indigenous, Spanish, African, Asian, and European descendants (Blanco 1985; Lavriega Monforti 2014). In recognition of this intermixing, the US Census Bureau classifies Latin@s in both racial and ethnic terms, leading to the popularity of the term Hispanic. In an effort to distinguish Latin@s from the US dichotomized understanding of race, latinidad offers a potential unifying factor for Latin@s in the United States (Lavriega Monforti 2014).

Conversely, Latin@ identity may coexist with affiliations of Latin-American identity. Although Latin@s primarily identify with their country of origin, the overlapping of latinidad and national origin will vary depending on the context and social interactions (Diaz Mcconnell and Delgado-Romero 2004). For example, if a Latin@ is in a mainstream professional setting, he or she may identify as Latin@, whereas in the company of other Latin@s he or she will stress his/her national origin of identity, e.g. Venezuelan, Mexican, etc. Indeed, Latin@s will adhere to their own particular identities before embracing Latin@panethnicity (Calderon 1992; Jones-Correa and Leal 1996). In short, Latin@s may assume one label or the other depending on the social environment (Diaz Mcconnell and Delgado-Romero 2004; Sommers 1991). For example, in the political arena, Puerto Rican and Chicano activist groups in Chicago unite around collective action coining the term Latin@ although they have distinct national identities. A common language and an awareness of being different from other social groups enabled political mobilization in response to common structural conditions in education, housing, and economics. Consequently, panethnic unity among Latin@s is situational specific (Calderon 1992).

Thus, latinismo in the United States is an "imagined community" that commands deep emotional legitimacy (Anderson 2006; Sommers 1991). Jones-Correa (1996) posits that Latin@ panethnicity is a complex phenomenon as individuals merge multiple identities in different ways. Latin@ groups in the United States are fairly distinct even internally. Panethnic unity is possible for collective action, but the development of a Latin@ identity in practice is yet to be seen (Calderon 1992). Nevertheless, there is a trend of implicit homogenization that denies the national, linguistic, social, cultural, gendered, racial, religious and political experiences of Latin Americans (Jones-Correa and Leal 1996). As I will discuss later, both Latin@ and mainstream media in the United States portray Latin@ panethnicity as a reality, blending distinct identities into one.

\section{Blacks in Latin America, the Hispanic Caribbean, and the Ideal of Mestizaje}

As previously stated, latinidad manifests for instrumental reasons such as activist action. Political outcomes and media marketing strategies that unite Hispanics under the flag of Latin@ identity engulf the differences among groups. However, the invisibility of certain group characteristics, such as race, is rooted in a history of colonialism.

A majority of Hispanic Caribbean and Latin Americans possess a mixture of Indigenous, European, and African heritage. After centuries of miscegenation, there are numerous racial variants in each nation. Latin American countries have been classified as mestizo nations with indigenous and Hispanic heritage. Countries with visible Afro-Latin American heritage include Brazil and the Spanish-speaking 
Caribbean, which displays a black and white racial range and has a history of plantation-based slavery (Sue and GolashBoza 2009; Ribando 2007). However, it is important to note that Africa permeates throughout Latin America and the Hispanic Caribbean.

Mestizaje is the dominant racial ideology in Latin American countries (Hartigan 2013). For example in Mexico, individuals were labeled mestizo if they were the offspring of a Spanish (or of Spanish descent born in the Americas) and an indigenous individual (M. E. Martinez 2008; Hartigan 2013). Nonetheless, the term mestizo is ambiguous as it can also be applied to people with African ancestry which is the case in Panama (Watson 2014). Likewise depending on their position within the color spectrum, individuals are labeled "indio" in the Dominican Republic (Sidanius, Pena, and Sawyer 2001). The reference and further glorification of the Amerindian lineage in the national discourse serves to conceal blackness. Consequently, mestizaje promotes a combined biological and cultural European and indigenous heritage (Hartigan 2013). Even though this notion contrasts the bipolar racial understanding in the United States, where whiteness is a normative identity, it too outlines forms of racial exclusion (Hartigan 2013; Ong 2003) as it ignores the marginalization of indigenous peoples and draws a distinction between these groups, Blacks (Whitten and Torres 1992; Hartigan 2013) or their mixed offspring.

Accordingly, national discourses in Latin America and the Caribbean exclude Afro descendants and emphasize a mestizaje discourse, thus blurring racial identities into a homogenization project (Watson 2014). Furthermore, the mestizaje ideology places blackness at the margins of the nation (Godreau 2002). Take the examples of Panama and Puerto Rico which were intervened by the United States as a result of expansionist projects of the $19^{\text {th }}$ and early $20^{\text {th }}$ centuries. To reaffirm its Hispanic identity to Latin America and the world, Panamanian nationalists reinforced the notion of a mestizo, Catholic, and Spanish-speaking nation (Watson 2014). Although Puerto Rico is a colony of the United States with limited political power, most Puerto Ricans consider themselves part of a distinct national group (Dávila 1997; Morris 1995; Godreau 2002). Thus, an ideology of racial mixture was articulated to distinguish between a deeply segregated United States "other" and a racially democratic Puerto Rico (Godreau 2002).

Because of this perceived hybridity, Latin@s habitually reject a binary ( Black / White) understanding of race (Itzigsohn 2004). Scholars have found low levels of Black consciousness and a denial of a Black identity in Brazil, Venezuela, Colombia, Puerto Rico, and the Dominican Republic (Sue and Golash-Boza 2009). When identifying as Hispanic or Latin@ in the United States, most Caribbean and Latin Americans distance themselves from a Black racial identity (Rodríguez 2000). Consequently, the racialization of ethnicity allows Latin@s to escape their labeling as Black and affords them with a language to articulate their experiences as a racial other within the black-white paradigm (Itzigsohn 2004; Lavriega Monforti 2014).

The contributions of Blacks in the construction of Hispanic Caribbean and Latin American nations and culture are undeniable. Independence efforts during the $19^{\text {th }}$ and $2 \mathrm{O}^{\text {th }}$ centuries included the core participation and support of Afro-Latin@ Americans. Furthermore, African-informed music and dance that were once rejected by the governing elites are embraced as national symbols today. The State recognizes African practices and customs and relocates them from their original contexts through a process called folklorization in performances (festivals or folkloric dances), promoting national culture as the cohesive product of different socio-racial heritages (Urban and Sherzer 1991; I. Martinez 2002; Lewis 2000; Dávila 1997; Godreau 2002). Consequently, in the Caribbean and Latin America, Afro identity fades into the national identity discourse (Hernandez 2003; Sue and Golash-Boza 2009). This national rhetoric celebrates racial synthesis and European White aesthetics while negating Black heritage (Dixon 2006; CruzJanzen 2003; Denton and Massey 1989). National ideologies operate as a vehicle to strengthen Eurocentrism hindering the participation of Blacks in politics, law, media, education, and other fields (Quiñones Rivera 2006).

Even more, race is conceptualized on a color continuum, which enables individuals of African descent to distance themselves from blackness (Sue and Golash-Boza 2009). Lighter skinned Blacks may identify as White, while some darker skinned Blacks may identify as mulattoes or mestizos (Ribando 2007). Some Latin@s claim that they are a more racially congruous people as a consequence of their mixedrace inheritance. For example, Mexicans subscribe to the notion that Blacks were assimilated and spent little time as a recognizable community (Hernandez 2003). Dominicans see themselves as Indio or Indian, while classifying Haitians as Black (Sue and Golash-Boza 2009; Newby and Dowling 2007; Ribando 2007). In Panama, West Indians that arrived to work in the construction of the Canal at the beginning of the $20^{\text {th }}$ century are negros while Panamanians of African descent are ambiguously cataloged as mulatos, mestizos or morenos depending on their skin color and phenotype (Watson 2014) . $^{3}$

Incidentally, these classifications are often influenced by social status (Ribando 2007). For example in Brazil, race is related to socioeconomic status and discursive practices that hinder Blacks from advancing in professional and social circles (Dixon 2006). Likewise, many Caribbean and Latin American countries preach an artificial homogeneity but historically, Black individuals have faced various forms of racial discrimination. Racism pervades the daily discourse. In Puerto Rico, expressions like mejorar la raza or "improve" the race by marrying whiter or referring to African hair as pelo malo or bad hair undermine Afro descendants. In Mexico, phrases such as "working like a black", "getting black"s or "a 
supper of blacks"6 (Hernández 2004) are racially offensive, yet are common and accepted.

Afro-Latin@s comprise a majority of the population in Cuba and the Dominican Republic, and a significant minority in Colombia, Panama, Venezuela, Ecuador and Nicaragua. Furthermore, "[b] razil has the largest Afro-descendant population outside of Africa" (Ribando 2007). When Black Latin@s come to the United States, the reception is lukewarm. Many experience a lack of acceptance from the Hispanic community who question their presence and sense of belonging. For example, Quiñones (2006), an Afro-Puerto Rican in the United States, claims she has to negotiate her identity among Latin@s who habitually express, "You don't look Latina" (174). Likewise, a study about Afro Cubans in the South West revealed they disliked being regarded as Hispanic because they sensed they lacked common experiences with Mexicans. On the other hand, Afro Cubans feel that African Americans deny their blackness because of a lack of shared history and common experiences (Roth 2009). By contrast, Puerto Ricans in New York City and Chicanos in the West Coast identified with the African-American community developing transethnic connections through hip-hop music (Rivera 2001).

\section{Latin American media portrayal of Blacks}

Media characterizations of ethnic and cultural minorities are generalizations that rely on overly broad categorizations (Trimble 1991; Diaz Mcconnell and DelgadoRomero 2004), or stereotypes. A stereotype is a cognitive and affective assessment following the categorization of a person into a social, cultural, or racial group (Drakulich 2012; Hilton and Von Hippel 1996; Macrae and Bodenhausen 2000). Stereotypes are automatically activated with the mere presence of certain attributes of the referenced group (Bargh, Chen, and Burrows 1996; Herz and Diamantopoulos 2013). Under those circumstances, racial frames function on an unconscious level, making beliefs about other individuals appear less like prejudice and more normative (Haney López in Hernández, 2004). Media dictates much of what society understands about ethnic minorities. Because stereotypes are so ubiquitous in the media, the label for that group is primed and automatically triggered and impacts how we process judgments of the person. In this way, media may contribute to the shaping of ethnic stereotypes (Gorham 1999; Devine 1989; Patton 2001; Tan, Fujioka, and Lucht 1997).

Although a number of Hispanic Caribbean and Latin American countries struggle with their racial identities, I will briefly discuss the portrayal of blackness in Brazilian, Colombian, Peruvian and Puerto Rican media. Even though there are prominent black politicians, musicians, singers, and sports figures, there are few embodiments of mediated blackness. To reiterate, the general cultural rhetoric in the $20^{\text {th }}$ century aimed to contrast with United States binary notions of race by upholding racial democracy (Rivero 2005; Blanco 1985). Consequently, blackness is erased or misrepresented in the media. However, the images of Black people that do appear on the airwaves are customarily presented as stereotypical.

Brazil. Notwithstanding there is a majority of Black or mixed race population, Brazilian media is overpoweringly dominated by Whites (Douglas 2015). Afro-Brazilians have not featured prominently on any of Brazil's three major networks, Rede Globo, Sistema Brasileira de Televisão and Rede Manchete (Lindsey 2007). Historically, seventy-five percent of the roles for black actors in the influential Brazilian soap opera industry were as domestic servants, poor or criminal (Araújo 2000). In addition, blackface characters are cast as domestic servants, poor, or as criminals. The television show Zorra Total featured comedian Rodrigo Sant'Anna as Adelaide, a dark-skinned, toothless, ugly female beggar who typifies Black stereotypes like laziness and ignorance (Willis 2016; Mastro and Greenberg 2000; Mastro and Stern 2003). However, since the 2000 s Blacks have created their own media and increasingly played non stereotypical roles (Lindsey 2007). In 2007, TV da Gente or the People's TV premiered offering programming primarily geared toward Afro-Brazilians (Lindsey 2007). In 2015 Globo, Brazil's main television network, broadcasted Mister Brau, a musical sitcom featuring a wealthy black couple in a lead role (Douglas 2015); a feat deemed as unprecedented. Also, television news are incorporating Black presenters, like the evening newscast Jornal Nacional that features Maria Julia Coutinho, a black weather reporter (Douglas 2015).

Colombia. Historically, Colombian television has discriminated against Afro-Colombians (Karabalí 2015). For example, in the 1980 s the telenovela La Pezuña del Diablo featured actor Ronald Ayaso in blackface playing a black character (Karabalí 2015). Furthermore, Afro-Colombian actors are usually portrayed as poor, maids, janitors, or criminals, and not in lead roles as in Sin tetas no hay paraiso, a telenovela based on the novel by Gustavo Bolívar, and Las detectives y el Víctor (Karabalí 2015). When RCN Television bought the Spanish-language rights to Grey's Anatomy, it did not cast any Black actors despite the fact that the original show featured African Americans in leading roles (Latino Rebels 2015; Karabalí 2015).

Recently, a blackface character incited the AfroColombian community's outrage. Soldado Micolta was a soldier character played by comedian Roberto Lozano on Caracol's Sábados Felices (Betancourt 2015). Like many Black characters, Micolta spoke with an accent and mispronounced Spanish words (Segura 2018; Nieves-Pizarro and Mundel 2017; Karabalí 2015). Micolta possesses stereotypical characteristics often assigned to Black characters such as intellectual deficiency, boastfulness, clumsiness and laziness (Mastro and Greenberg 2000; Mastro and Stern 2003; Karabalí 
2015). The character inflamed protests against the television network that broadcasted the sketch show and in the Ministerio de Tecnologías de la Información y las Comunicaciones that regulates media (Karabalí 2015). Caracol TV eventually eliminated the sketch from Sábados Felices after intense public pressure (Vargas 2015; Segura 2018).

Perú. Peruvian media reinforces racial stereotypes on a daily basis (Collyns 2010). For instance, tabloid newspapers use sexual innuendo to describe a black congresswoman or liken a black soccer player to a gorilla when he loses his temper (Collyns 2010). Moreover, a blackface character called El Negro Mama showcased in Frecuencia Latina's El Especial del Humor sparked outrage among Afro-Peruvian activists. El Negro Mamá, played by Jorge Benavides, is a caricature of a black man that exaggerates African features by using prosthetic nose and lips and a blackened face (Tegel 2013). Popular demand kept the blackface character on air in spite of being fined and receiving criticism from civil rights organizations (Collyns 2010). Benavides also plays a redface character called La Paisana Jacinta on Frecuencia Latina that mocks indigenous persons (Garcia 2015). On the other hand, Afro-Peruvian soccer players are often the objects of ridicule though blackface. In 2015 Jefferson Farfán and André Carrillo were mocked by Jorge and Alfredo Benavides on a popular show on Frecuencia Latina after they made headlines for attending a high-profile celebrity wedding (Betancourt 2015). Farfán was ridiculed again in 2018 by comedian Miguel Moreno when he was depicted as a dimwit blackface fool who flirted with a beauty queen on Peru's FOX Sports $^{7}$ (Reuters 2018).

Puerto Rico. Media representations of racialized women traditionally deployed a folkloric image of African heritage such as Mamá Inés, a mammie-like figure that a popular coffee brand uses as a spokesperson in television ads. Another embodiment of blackness in Puerto Rico features blackface characters. Aired by Telemundo in the 1950s, Diplo, short for Diplomacia (or Diplomacy), was first a black voice in the radio and later a blackface character. Diplo mirrored Cuban bufo characters that were imported through radio and cinema due to the close relationship between both nations before the triumph of the Revolution. Diplo the character was an anti-hero, illiterate, lazy, street wise and deceitful, all stereotypical characteristics of Black characters (Mastro and Greenberg 2000; Mastro and Stern 2003). Rivero on the other hand, was an all-around media professional: an actor, producer, scriptwriter and songwriter as well as director for theatre, film, radio and television; a pro-independence advocate, and a philanthropist. The audience revered him and his blackface depiction in Diplo (Rivero 2005).

Another blackface character Chianita la Negra, played by actress Ángela Meyer, appeared in media during elections to promote her nomination as Governor (Garcia 2016). Chianita is portrayed as a street smart, yet uneducated Black woman who does not speak Spanish well as she mispronounces her slogan as "voten por yo", instead of "voten por mí" (Garcia 2016). In 2016, Meyer asked her social media followers if they wanted her to revive the character for the elections taking place that year. While many supported the character, anti-racism activists and human rights organizations opposed the idea and even celebrated a "burial" to symbolically put to rest the practice of blackface (Abadía-Rexach 2016; Peña López 2016; Garcia 2016).

Pirulo el Colorao is another blackface character that appeared in Qué Vacilón, (WAPA Television) a sketch comedy show led by comedian Raymond Arrieta during the 1990s. Pirulo appeared dancing and singing bomba music (an Afro-Puerto Rican dance genre). Rivero (2005) explains that Pirulo reminded Puerto Ricans that everyone has Black ancestry when he made the live audience say "¿Y tu abuela dónde está?" or "Where is your grandmother," a verse from Fortunato Vizcarondo's poem of the same name that questions why Black relatives were hidden. Likewise, Pedro Fosas Nasales, Peyo el Prieto, Cuco Pasurín, and Willie el Merenguero (Abadía-Rexach 2016; Garcia 2016) are other blackface characters that entertained Puerto Rican audiences by mocking blackness.

Finally, in the 1990s, Telemundo aired the situation comedy Mi Familia, the first featuring a Black family. Inspired by US Black-oriented sitcoms like The Jeffersons and The Cosby Show, Mi Familia followed the life of the Black lower-middle class Meléndez family (Rivero 2002; 2005). Nonetheless, the leading actress Judith Pizarro posited that the program was about "a Puerto Rican family which happened to be Black", furthering the national discourse of a mestizo Puerto Rican family (Rivero 2002; 2005). The show was absent of racial and social topics and intended to present blackness in a positive light (Rivero 2002; 2005). This has been the only show to date that has presented a Black family in Puerto Rico's 64-year commercial television history (Rivero 2002; 2005).

\section{United States Latin@ Media depictions of Afro-Latin@s}

Thanks to advances in communication technologies and media, many Latin@s stay in contact with the diaspora in the United States and vice versa. Roth (2009) questions the elasticity of panethnic boundaries and their application to transnational migration. Transnationalism often enables dual identities to ethnic groups in a host nation as they develop links to distant societies. In turn, these symbolic identifications with other Latin@groups create panethnic consciousness within the United States and Latin America. Consequently, the media promotes a transnational panethicity (Roth 2009).

In Latin@electronic and print media the use of Spanish connects markets in the United States and Latin 
America, strengthening a million-dollar international Spanish-speaking public that transcends borders and nationalities. The constant migration and the geographic proximity of the sending countries sustain cultural bonds with Latin America. However, the closeness of Latin America keeps national identities alive (Sommers 1991). Rodríguez (1997) envisioned that Hispanic media should rely on racial differences to distinguish itself from the mainstream. Nonetheless, media representations have contributed to the invisibility of Afro-Latin@s, as black characters are rarely seen in Spanish-language television or film. This invisibility is deeply rooted in the subtle interplay between gross economic disparities and historic racism (Lindsey 2007).

The embodiment of Spanish-speaking people of African descent in the media has been limited to figures such as salsa singer Celia Cruz (Roth 2009). In October 2015 Telemundo aired the musical telenovela Celia based on the life of the Afro-Cuban entertainer (Jacobson 2015). Although Celia is a welcomed effort to showcase Afro-Latin@ contribution to Latin@ culture, there is still much work to be done. Still Afro-Latinos are ridiculed in Latin American media and their voices are muted in the United States Latin@ and mainstream media (Garcia 2015).

Since productions similar to Celia are scarce in Latin@ US media, most programs promote a homogenized concept of Latin@ identity. These cultural products are also broadcasted in Puerto Rico and other Latin American countries. For Latin@s in the United States, ethnic media continually refreshes and reinforces Spanish language. Audience researchers and marketers use language as a proxy for lower socioeconomic class Hispanics. English language use is a sign of acculturation and higher socioeconomic status (Rodríguez 1997; Alba and Nee 2003; Sommers 1991).

The success of Hispanic media will be determined by the level of Latin American immigration and the socioeconomic development of U.S. Latin@ communities (Rodríguez 1997). Specifically, U.S.-born millennial Latinos are increasingly consuming Spanish Language media because of streaming services such as Netflix, Amazon, and Hulu. Young Latin@s are rediscovering content from traditional media giants such as Univision and Telemundo (Carrasco 2017). However, this is problematic because the representation of latinidad as seen in Latin@ media remains decidedly European (Davila 2001; Roth 2009). Few programs challenge stereotypical roles of black and indigenous Latin@s (e.g. Biographical series Celia, 2015). Latin@ content producers such as $\mathrm{Mitu}^{8}$ and Remezcla ${ }^{9}$ are driving a phenomenon called "digital reculturation" or the process of rediscovering one's culture of origin / identification through digital representations of culture through online platforms (Carrasco 2017). Online media features a diverse Latin@ cast and often addresses issues of race and intra Latin@stereotypes.

\section{Representation of Latin@s in US Media}

Throughout the history of US television and film, Latin@s have been portrayed in a derogatory way. During the silent film era, Mexican characters were depicted as a menace to American land ownership, challenging the southwestern history of Mexican land dispossession. In addition, Mexican Americans were portrayed as volatile, untrustworthy, violent, animal-like, and as thieves. This was the case of the Cisco Kid ${ }^{10}$ (Behnken and Smithers 2015).

Latin@men and women were depicted as highly sexualized. For instance, Zorro was a Robin Hood-like bandido and a Latin lover. White actresses in brownface spoke in overly accented ways, dressed stereotypically, and were portrayed as highly sexualized objects or Latina lovers. Often, Mexican and Cuban fireball films shared a plot pattern: "a recent immigrant arrives in America, finds wealth, fame or fortune, encounters a bad guy and is rescued by a white benefactor" (Behnken and Smithers 2015).

One classic depiction of Latin@s as delinquent and highly sexual was the musical West Side Story in 1961. In the United States, Puerto Ricans are racialized as different from, but sharing with African Americans a collective subservience to Whites. Therefore, they were deemed as dangerous others who participate alongside African American social spaces, conditions and dispositions (Rivera 2001). West Side Story depicted Puerto Ricans as delinquent, urban bandidos. Although labeled a modern Romeo and Juliet, West Side Story addressed the tragedy of interethnic sexual relations instead of issues of family and social status (Behnken and Smithers 2015).

In television, few shows in the US mainstream media have featured (Afro)Latin@ as lead characters. In the 1950s, I Love Lucy featured Cuban Desiderio 'Desi' Arnaz alongside Lucille Ball. Later, during 1970s Chico and the Man, Friends and Lovers, Fantasy Island and 9 to 5 had Latin@ leads. In the 1980s, Chips was added to the list; and in the 1990s NYPD Blue, Union Square and Malcom in the Middle featured Latin@ actors. During the $21^{\text {st }}$ century, Desperate Housewives and Modern Family featured a sexualized portrayal of Latinas (Negron-Muntaner et al. 2014) ${ }^{11}$.

Today, Latin@s only represent 5.8 percent of speaking roles in mainstream media (Betancourt 2018; Scannel 2017). Despite this, Latin@ representation in U.S. media is increasing. Mexican-American comedian George López ${ }^{12}$ starred in his own sitcom and late night TV show between 2002-2007. In addition, Cristela ${ }^{13}$, Jane the Virgin ${ }^{14}$, and One Day at a Time ${ }^{15}$ are three situation comedies that do not portray Latina leads as sexualized, but as middle-class second generation Latin@s in the United States who navigate between their Latin@ and American identities. Moreover, mainstream media is addressing diversity in an effort to appeal to an upcoming multiethnic millennial generation. The ABC Family cable network has implemented this strategy and includes representation 
of Latin@ characters in series such as The Secret Life of the American Teenager, Pretty Little Liars, Switched at Birth, and The Fosters (Hochhalter 2013).

Similarly, the visibility of Afro-Latin@s has increased in recent years in U.S media. Afro-Puerto Rican actress Rosario Dawson and Afro- Dominican actress Zoé Saldaña are becoming more prominent in film and television by playing mainstream non-racialized characters. Still, Afro-Latin@ actors are not featured prominently in US television or film (Negron-Muntaner et al. 2014).

\section{Conclusion}

The idea of a Latin@ identity is promoted by structural forces in the United States and reinforced by the media. Yet, the heterogeneity of Latin@ groups in terms of nation and race make it difficult to articulate a global Hispanic culture. Latin@s are first loyal to their home countries, and second to the idea of being Hispanic. Thus, latinidad is still an instrumental means to obtain rights and recognition in the United States; yet a weak tool to unite Latin@s under the same cultural umbrella.

Media are one of the main producers of culture. Latin@ and mainstream television feature panethnic notions of latinidad, although new programing and actors are challenging stereotypical roles. Nevertheless, the representation of latinidad as seen in Spanish-language and U.S. media remains decidedly not black (Davila 2001; Roth 2009). The portrayal of Latin@s in general is still lacking in media. Black individuals in Latin America are invisible in local media as nationalist discourses tend to Hispanicize or whiten power and culture. Afro-Latin Americans struggle to make themselves visible in their lands. Perhaps their portrayal in U.S. Latin@ and mainstream media will force Caribbean and Latin American countries to come to grips with the idea that our nations were also built on African blood and eventually redefine the assumptions about Black participation in society (Lindsey 2007).

\section{REFERENCES}

Abadía-Rexach, Bárbara I. 2016. “El Duelo Del Racismo.” El Nuevo Día, November 7.

Alba, R., and V. Nee. 2003. Remaking the American Mainstream: Assimilation and Contemporary Immigration. Cambridge, Mass.: Harvard University Press.

Anderson, Benedict, 2006. Imagined Communities: Reflections on the Origin and Spread of Nationalism. Verso.

Araújo, Joel Zito. 2000. “A Negação Do Brasil.” Brazil.

Bargh, J. A., M. Chen, and L. Burrows. 1996. "Automaticity of Social Behavior: Direct Effects of Trait Construct and Stereotype Activation on Action." Journal of Personality and Social Psychology 71: 230-44.

Behnken, B., and G. D. Smithers. 2015. Racism in American Popular Media: From Aunt Jemima to Frito Bandito. Santa Barbara, California: Praeger.

Betancourt, Manuel. 2015. "10 Egregious Uses of Blackface on Spanish-Language Television.” Remezcla, November 2.

Betancourt, Manuel. (2018). "There Are More Latinos on TV, But Is That Really Progress?” Remezcla, January 5.

Blanco, Tomas. 1985. El Prejuicio Racial En Puerto Rico: Con Estudio Preliminar de Arcadio Díaz Quiñones. Río Piedras, Puerto Rico: Ediciones Huracán.

Bradley, L. (2018, January 26). How One Day at a Time Captures a Community Most TV Ignores. Vanity Fair. New York, NY.

Calderon, Jose. 1992. "'Hispanic' and 'Latino' The Viable Categories of Panethnic Unity." Latin American Perspectives 19 (75): 37-44.
Carrasco, Mario. 2017. "Why Are Hispanic Millennials Streaming More Spanish-Language Content?” Media Post, August 9.

Cohn, D'vera, Eileen Patten, and Mark Hugo Lopez. 2014. "Puerto Rican Population Declines on the Island, Grows on the Mainland." Pew Research Center Hispanic Trends Project, August.

Collazo, Sonia G, Camille L Ryan, and Kurt J Bauman. 2010. "Profile of the Puerto Rican Population in the United States and Puerto Rico: 2008." Dallas, TX.

Collyns, Dan. 2010. "Peru's Minorities Battle Racism.” BBC News, June 13.

Cruz-Janzen, Marta I. 2003. "Out of the Closet: Racial Amnesia, Avoidance and Denial - Racism among Puerto Ricans.” Jean Aot Belkhir, Race Gender \& Class 10 (3): 64-81.

Davila, A. 2001. Latinos, Inc.: The Marketing and Making of a People. Berkeley, CA: Berkeley, CA University of California Press.

Dávila, Arlene M. 1997. Sponsored Identities: Cultural Politics in Puerto Rico. Philadelphia, PA: Temple University Press.

Denton, Nancy a., and Douglas S. Massey. 1989. "Racial Identity Among Caribbean Hispanics: The Effect of Double Minority Status on Residential Segregation." American Sociological Review 54 (5): 790-808. doi:10.2307/2117754.

Devine, P. G. 1989. "Stereotypes and Prejudice: Their Automatic and Controlled Components." Journal of Personality and Social Psychology 56 (1): 5-18. 
Diaz Mcconnell, Eileen, and Edward A Delgado-Romero. 2004. "Latino Panethnicity: Reality or Methodological Construction?” Sociological Focus 37 (4): 297-312.

Dixon, Kwame. 2006. "Beyond Race and Gender: Recent Works on Afro-Latin America." Latin American Research Review 41 (3): 247-57.

Douglas, Bruce. 2015. "Brazilian Television Slowly Confronts Country's Deeply Entrenched Race Issues.” The Guardian, October 7 .

Drakulich, K. M. 2012. "Strangers, Neighbors, and Race: A Contact Model of Stereotypes and Racial Anxieties About Crime." Race and Justice 2 (4): 322-55.doi:10.1177/ 2153368712459769.

Garcia, William. 2015. "Blackface, Brownface and Black Lives Matter in Latin America." Latino Rebels, August 5.

---. 2016. "The Burial of Chianita La Negra: White Fragility and Blackface in Puerto Rico." Latino Rebels, November 8.

Godreau, Isar. 2002. "Changing Space, Making Race: Distance, Nostalgia, and the Folklorization of Blackness in Puerto Rico.” Identities 9 (3): 281-304. doi:10.1080/10702890213969.

Gorham, Bradley W. 1999. "Stereotypes in the Media: So What?" Howard Journal of Communications 10 (4): 229-47. doi:10.1080/106461799246735.

Hartigan, John. 2013. "Translating 'Race' and 'Raza' between the United States and Mexico." North American Dialogue 16 (1): 29-41. doi:10.1111/nad.12001.

Hernández, Tanya K. 2003. “'Too Black to Be Latino/a' Blackness and Blacks as Foreigners in Latino Studies." Latino Studies I: 152-59.

Hernández, Tanya K. 2004. "Afro-Mexicans and the Chicano Movement: The Unknown Story.” California Law Review 92 (5): 1537-51. doi:10.2307/3481424.

Herz, M. F., and A. Diamantopoulos. 2013. "Activation of Country Stereotypes: Automaticity, Consonance, and Impact." Journal of the Academy of Marketing Science 41: 400-417.

Hilton, J. L., and W. Von Hippel. 1996. “Stereotypes.” Annual Review of Psychology 47: 237-271.

Hochhalter, Johannah Maria. 2013. "Latina/o Representation on Teen Oriented Television: Marketing to a New Kind of Family." University of Texas Austin.

Itzigsohn, Jose. 2004. "The Formation of Latino and Latina Panethnicities.” In Not Just Black and White: Historical and Contemporary Perspectives on Immigration, Race and Ethnicity in the United States, edited by Nancy Foner and George M. Fredrickson, 197-216. New York, NY: Russell Sage Foundation.

Jacobson, A. 2015. “Telemundo Turns Its Lenses on 'Celia.” Multichannel, October.

Jones-Correa, Michael, and David L. Leal. 1996. "Becoming 'Hispanic': Secondary Panethnic Identification among Latin American-Origin Populations in the United States." Hispanic Journal of Behavioral Sciences 18 (2): 214-54. doi:0803973233.
Karabalí, Jesús. 2015. "Racismo En La Televisión Colombiana: No Más Soldado Micolta.” Las 2 Orillas.

Latino Rebels. 2015. "Afro-Colombians Condemn Blackface Soldier TV Character." Latino Rebels, October 15.

Lavriega Monforti, Jessica. 2014. "Identity Revisited: Latinos(as) and Panethnicity." In Latino Politics En Ciencia Politica: The Search for Latino Identity and Racial Consciousness, edited by Tony Affigne, Evelyn Hu-Dehart, and Marion Orr. New York: New York University Press.

Lewis, Laura. 2000. "Blacks, Black Indians, Afromexicans: The Dynamics of Race, Nation, and Identity in a Mexican Moreno Community (Guerrero).” American Ethnologist 27 (4): 898-926.

Lindsey, Shawn. 2007. "Black TV in Brazil: Power to the People." Black Agenda Report, February 27.

Macrae, C. N., and G. V. Bodenhausen. 2000. "Social Cognition: Thinking Categorically about Others.” Annual Review of Psychology 51: 93-120.

Martinez, Iveris. 2002. "Danzas Nacionalistas: The Representation of History through Folkloric Dance in Venezuela." Critique of Anthropology 23 (3): 257-282.

Martinez, Maria Elena. 2008. Genealogical Fictions: Limpieza De Sangre, Religion, and Gender in Colonial Mexico. Stanford, CA: Stanford University Press.

Mastro, D. E., and B. Greenberg. 2000. "The Portrayal of Racial Minorities in Prime Time Television." Journal of Broadcasting \& Electronic Media 44 (4): 690-703.

Mastro, D. E., and S. R. Stern. 2003. "Representations of Race in Television Commercials: A Content Analysis of PrimeTime Advertising." Journal of Broadcasting \& Electronic Media 47 (4): 638-47. doi:10.1207/s15506878jobem4704.

Morris, Nancy. 1995. Puerto Rico: Culture, Politics, and Identity. Westport, Conneticut: Praeger.

Motel, Seth, and Eileen Patten. 2012. "Hispanics of Puerto Rican Origin in the United States, 2010.” Pew Research Center Hispanic Trends Project, June.

Negron-Muntaner, Frances, Chelsea Abbas, Luis Figueroa, and Samuel Robson. 2014. "The Latino Media Gap: A Report on the State of Latinos in U.S. Media."

Newby, C Alison, and Julie A Dowling. 2007. "Black and Hispanic: The Racial Identification of Afro-Cuban Immigrants in the Southwest." Sociological Perspectives 50 (3):343-66. doi:10.1525/sop.2007.50.3.343.This.

Nieves-Pizarro, Yadira, and Juan Mundel. 2017. “iAzúcar! Afro Latin@s’ Representation in the Telemundo Series Celia: How Latino Media Articulates Blackness within Latino Panethnicity." In Asociation for Education in Journalism and Mass Communication. Chicago, IL.

Ong, Aihwa. 2003. Buddha Is Hiding: Refugees, Citizenship, the New America. Berkeley, CA: University of California Press.

Dave, P. (2016, December 13). For entertainment start-up Mitu, Facebook might be sharable but Snapchat's relatable. Los Angeles Times. Los Angeles, CA. 
Patton, T. O. 2001. "Ally McBeal and Her Homies: The Reification of White Stereotypes of the Other." Journal of Black Studies, 229-60.

Peña López, Brenda I. 2016. “Sepultan a 'Chianita’ Por Considerarla Racista.” El Nuevo Día, November 2.

Quiñones Rivera, Maritza. 2006. "From Triguenita to Afro Puerto Rican: Intersections of the Racialized, Gendered, and Sexualized Body in Puerto Rico and the U.S. Mainland." Meridians 7 (1): 162-82.

Reuters. 2018. "Peru: FOX Sports, Comedian Condemned for 'Blackface' Skit.” TeleSur, May 11.

Ribando, Claire M. 2007. "Afro-Latinos in Latin America and Considerations for U.S. Policy.” Washington, DC.

Rivera, R. Z. 2001. "Hip-Hop, Puerto Ricans and the Ethnoracial Identities in New York.” In Mambo Montage: Latinization of New York, edited by Agustin Lao-Montes and Arlene Davila. New York, NY: Columbia University Press.

Rivero, Yeidy M. 2002. "Erasing Blackness: The Media Construction of 'race' in Mi Familia, the First Puerto Rican Situation Comedy with a Black Family.” Media, Culture \& Society 24 (4): 481-97. doi:10.1177/016344370202400402.

Rivero, Yeidy M. 2005. Tuning out Blackness: Race and Nation in the History of Puerto Rican Television. Durham: Duke University Press.

Rodriguez-Cortez, Carmen. 1990. "Social Practices of Ethnic Identity: A Puerto Rican Psycho-Cultural Event.” His 12 (4):380-96.

Rodríguez, América. 1997. "Commercial Ethnicity: Language, Class and Race in the Marketing of the Hispanic Audience." The Communication Review 2 (3): 283-309. doi:10.1080/10714429709368561.

Rodriguez, Clara. 2000. Changing Race: Latinos, the Census, and the History of Ethnicity in the United States. New York, NY: New York University Press.

Roth, Wendy D. 2009. "'Latino before the World': The Transnational Extension of Panethnicity." Ethnic and Racial Studies 32 (6): 927-47 doi:10.1080/01419870 802245042 .

Scannel, Herb. 2017. "Neglecting the Latino Community Is Hollywood's Multibillion-Dollar Missed Opportunity.” AdWeek, November 16.
Segura, Camila. 2018. "No Soy Tu Chiste.” Radio Ambulante. Colombia: Radio Ambulante. http://radioambulante.org/ en/audio-en/im-not-your-joke.

Sidanius, Jim, Yesilernis Pena, and Mark Sawyer. 2001. "Inclusionary Discrimination: Pigmentocracy and Patriotism in the Dominican Republic." Political Psychology 22 (4): 827-51. doi:10.1111/0162-895X.00264.

Sommers, Laurie Kay. 1991. "Inventing Latinismo: The Creation of 'Hispanic' Panethnicity in the United States." The Journal of American Folklore 104 (411): 32-53. doi:10.2307/541132.

Sue, Christina A., and Tanya Golash-Boza. 2009. "Blackness in Mestizo America.” Latino(a) Research Review 7 (1-2): $30-58$.

Tan, A., Y. Fujioka, and N. Lucht. 1997. "Native American Stereotypes, TV Portrayals, and Personal Contact.” Journalism and Mass Communication Quarterly 74: 265-284.

Tegel, Simeon. 2013. "Peru's Blackface 'Negro Mama' Continues to Offend." Public Radio International, December 21.

Trimble, Joseph E. 1991. "Ethnic Specification, Validation Prospects and Future of Drug Abuse Research." International Journal of the Addictions 25: 149-69.

Trimble, Marshall. 2015. “The Cisco Kid”. True West: History of the American Frontier. Retrieved July 19, 2018 from https:/ truewestmagazine.com/the-cisco-kid/

Urban, Greg, and Joel Sherzer. 1991. "Indians, Nation-States, and Culture." In Nation-States and Indians in Latin America, edited by Greg Urban and Joel Sherzer. Texas: Texas University Press.

Vargas, Andrew. 2015. "Blackface Character Soldado Micolta Removed From Colombian TV After Protests.” Remezcla, November 4.

Watson, Sonja. 2014. The Politics of Race in Panama: AfroHispanic and West Indian Literary Discourses of Contention. Gainesville, FL: University Press of Florida.

Whitten, Norman, and Arlene Torres. 1992. "Blackness in the Americas.” Report on the Americas 25 (4): 16-46.

Willis, Kiersten. 2016. "From Iran to Peru: 10 Countries You Didn't Know Participate in Racist Blackface Traditions." Atlanta Black Star, April 21.

\section{ENDNOTES}

1 The term Latin@ is used as a gender encompassing term to denote equality.

2 According to Anderson (2006) an imagined community is characterized by kinship and citizenship. Although communities have fiscal boundaries, imagined communities may stretch out to other nations as a sovereign entity. Finally, a profound comradeship and fraternity bonds its members.

3 In this paper the term Afro-Latin@ includes Blacks and Mulattos.

4 In Mexico, the phrase "trabajar como negro" (in English working like a black), is employed in allusion to someone 
who is working too hard or too much such as blacks who were subject to slavery.

5 In Mexico, the phrase "ponerse negro" (In English getting black) depicts someone who becomes angry (Hernández 2004).

6 In Mexico the expression "una cena de negros" (In English a supper of blacks) is used to reference a disorderly crowd (Hernández 2004).

7 Although it is unclear, this parody may have made reference to an encounter between US rapper 50 cent and Fox Sports Reporter Erin Andrews in 2015, when the former kissed her. The kiss was not well received by Andrews.

8 Mitu is a Latino digital media company that produces news and entertainment content for English-speaking Latinos who want to remain connected to their heritage (Dave 2016).

9 Remezcla is an alternative media targeted to Latin@ millennials that showcases Latin@music, culture, and events.

10 The Cisco Kid is a Mexican bandido who appeared in film, radio, and television during the first half of the $20^{\text {th }}$ century. In his first incarnation he was depicted as a murdering criminal. In the 1950 s, he was rebranded as a role model and represented as a noble gentleman in a television series (Trimble 2015).
11 Freddie Prinze (Chico and the Man) is of Puerto Rican and Hungarian descent; Paul Sands (Friends and Lovers) is of Mexican and Russian descent; Ricardo Montalbán (Fantasy Island) is of Mexican descent; Rita Moreno (9 to 5) is of Puerto Rican descent; Eric Estrada (Chips) is of Puerto Rican descent; Jimmy Smits (NYPD Blue) is of Puerto Rican descent; Daphne Rubin-Vega in Union Square is of Panamanian descent; Franke Muñiz (Malcom in the Middle) is of Puerto Rican and Italian descent. Eva Longoria (Desperate Housewives) is of Mexican descent; Sofia Vergara (Modern Family) is of Colombian descent.

12 George Lopez's sitcom deals with the life of a Latino comedian who balances work and family.

13 Cristela depicts a recent Latina law school graduate in search of the American Dream while juggling her work, family, and love life.

14 Jane the Virgin showcases a young Latina woman who becomes pregnant after being accidentally artificially inseminated.

15 One Day at a Time is a remake from a 1970s show with the same name that features a divorced military veteran mother who tackles family issues from a Latin@ perspective (Bradley 2018). 